Publicación semestral. ISSN 2215-4906

Volumen 80 - Número 2

Enero - Junio 2021

\title{
Los sueños de la globalización (re)producen banana republics. Óscar Figueroa como crítico de la globananalización
}

The Dreams of Globalization (Re)produce Banana Republics.

Oscar Figueroa as a Critic of Globananalization

\author{
Sergio Villena Fiengo
}

\section{(c) $(1) \Theta$}

Esta obra está bajo una licencia Creative Commons Reconocimiento-No comercial-Sin Obra Derivada 
Dossier

\title{
Los sueños de la globalización (re)producen banana republics. Óscar Figueroa como crítico de la globananalización ${ }^{1}$
}

The Dreams of Globalization (Re)produce Banana Republics.

Oscar Figueroa as a Critic of Globananalization

\author{
Sergio Villena Fiengo ${ }^{2}$ \\ Universidad de Costa Rica \\ Costa Rica
}

Recibido: 11 de mayo de 2020 Aprobado: 26 de noviembre de 2020

\begin{abstract}
Resumen
Este artículo ensaya una aproximación a la crítica y a la resistencia que se desarrolla desde el campo de las artes visuales a la globalización neoliberal en la que se inserta Centroamérica desde hace algo más de tres décadas. Para ese fin, se realiza primero una caracterización de la inserción subalternizada de la región en la globalización neoliberal (la globananalización), con la cual se busca establecer sus vínculos estructurales y espectrales con el proceso de modernización periférica y la conformación de las mal llamadas banana republic. Con esa base histórica contextual, se analizan las modalidades de cuestionamiento y oposición al proceso de globananalización que, en los últimos unos años, viene realizando un trabajador del arte contemporáneo costarricense: Óscar Figueroa Chávez.
\end{abstract}

1 Este artículo, elaborado como parte de mis labores de investigación en el Instituto de Investigaciones Sociales (IIS) de la Universidad de Costa Rica (UCR), reproduce -reelaborando y ampliando- algunos fragmentos de mis textos "Construcciones / Invenciones: las imágenes de la nación en tres tiempos" (Villena, 2014b) y "Memories of the Glo-Ba-na-na-Lization. Geoeconomy and Contemporary Art in Central America" (Villena, 2018). Agradezco a Oscar Figueroa haberme facilitado y autorizado el uso de las imágenes que se incorporan en este escrito.

2 Profesor catedrático de la Escuela de Sociología y Director del Instituto de Investigaciones Sociales de la Universidad de Costa Rica (UCR). Doctor en Estudios de la Sociedad y la Cultura por la UCR. ORCID: 0000-0002-2864-8816. Correo electrónico: sergio.villena@ucr.ac.cr 
Palabras clave: arte contemporáneo; globalización; neoliberalismo; Centroamérica; Costa Rica

\begin{abstract}
This article attempts an approach to the criticism and resistance that develops in the field of visual arts to the neoliberal globalization in which Central America has been inserted for a little over three decades. To this end, a characterization of the subalternized insertion of the region in neoliberal globalization ("Globananalization") is first carried out, seeking to establish its structural and spectral links with the peripheral modernization and the formation of the so-called banana republic. With this contextual historical basis, the questioning and opposition to the globananalization process that Óscar Figueroa Chávez, a Costa Rican contemporary artist, has been carrying out for approximately a decade are analyzed.
\end{abstract}

Keywords: contemporary art, globalization, neoliberalism, Central America, Costa Rica 
Los sueños de la globalización (re)producen banana republics.

Dossier

Óscar Figueroa como crítico de la globananalización

Pongo primero bananos que hombres porque en las fincas de banano, la fruta ocupa el primer lugar, o más bien el único. En realidad el hombre es una entidad que en esas regiones tiene un valor mínimo y no está en el segundo puesto, sino que va en la punta de la cola de los valores que allí se cuentan... En las fincas de banano se le guardan más cons/deraciones a una mata de banano que a un peón.

(Carmen Lyra, 1931, p. 371).

La Compañía frutera Inc. Se reservó lo más jugoso, la costa central de mi tierra, la dulce cintura de América. Bautizó de nuevo sus tierras como "Repúblicas Banana"

(Pablo Neruda,1950, p. 237).

Los trabajadores reciben vales en vez de jornales. En vez de pago, deudas. Y abandonadas las plantaciones, que ya no sirven para nada, y dadas a colonias de desocupados.

Y la United Fruit Company en Costa Rica con sus subsidiarias la Costa Rica Banana Company y la Northern Railway Company y la International Radio Telegraph Company y la Costa Rica Supply Company pelean en los tribunales contra un huérfano.

(Ernesto Cardenal, 2019, p. 116).

Canibalizando el afortunado neologismo acuñado por el artista y curador nicaragüense Raúl Quintanilla, diremos que Centroamérica se encuentra en pleno proceso de "globananalización"3. Cediendo al canto de las sirenas neoliberales, desde inicios de la década de 1990, la región se ha insertado en la nueva división internacional del trabajo enmarcada en el mercado global. Pese a que los promotores de este proceso de liberalización

3 "Globananalización" es el título de un ensamble con el cual Raúl Quintanilla obtuvo el segundo premio en la Bienal Nicaragüense de Artes Visuales en el año 2001. Una descripción de esa pieza y de los significados que su autor y algunos críticos le asignan, se puede encontrar en la nota periodística "La globananalización” publicada en Nicaragua por El Nuevo Diario.

ESCENA. Revista de las artes, 2021, Vol. 80, Núm. 2 (enero-junio), pp. 221-252 
de la economía lo presentan como un requisito para lograr el siempre ansiado progreso o desarrollo, es cada vez más evidente que esta reinserción se ha llevado adelante sin que las naciones del istmo conjuren el estatus infame de banana countries que les fue impuesto desde inicios del siglo XX.

Los ajustes estructurales, las reformas del Estado y los tratados de libre comercio, mantienen a los países centroamericanos como proveedores de materias primas, entretenimiento turístico y mano de obra barata para explotaciones agrícolas y maquilas textiles o tecnológicas. A la vez, el istmo deviene mercado ampliado para los bienes industriales y para el capital comercial y financiero, que vende la ilusión de inclusión por medio del consumo y del endeudamiento. El resultado es poco halagüeño: democracias de baja intensidad, consumismo exacerbado, crecimiento de la pobreza, ampliación de la brecha de la desigualdad, precarización laboral, extractivismo recrudecido y deterioro ambiental acelerado. A eso se añaden la explotación sexual, la migración forzada, la corrupción estatal y la evasión fiscal privada, la violencia estructural y subjetiva, la crisis de los sistemas de justicia y la mano dura sobre los "peligrosos", entre otros problemas. Así, como lo resume William Robinson (2019), Centroamérica estaría experimentando una "segunda implosión".

Precisamente, en esta región del Sur llamada Centroamérica, marcada por su pasado colonial y por el capitalismo dependiente, periférico y subalterno, la globananalización es la manera en que ocurre aquello que César Rendueles (2015) ha denominado "capitalismo canalla". Ante este desolador panorama, son cada vez menos los que mantienen "lealtad" y muchos los que buscan una "salida" por la vía de la migración internacional, que cada vez asemeja más un éxodo masivo. Pero la "salida" también se relaciona con la creciente afiliación a iglesias neopentecostales, las cuales proliferan y devienen actores políticos de signo conservador, militantemente opuestos a los pocos avances logrados en términos de derechos de las mujeres y de las poblaciones sexualmente diversas.

Sin embargo, también están aquellos que levantan la "voz" y ejercen resistencia. Estos cuestionamientos y oposiciones a la globananalización asumen formas diversas y tienen como protagonistas a diferentes actores a lo largo y ancho de la región, entre los cuales destacan los movimientos sociales de diverso cuño y algunos creadores culturales. Asimismo, sobresale la labor de crítica y resistencia que surge desde múltiples disciplinas artísticas ${ }^{4}$, a

4 "Lealtad", "salida" y "voz" son categorías propuestas por Albert O. Hirschman (1970) en un ya clásico libro sobre la acción colectiva.

ESCENA. Revista de las artes, 2021, Vol. 80, Núm. 2 (enero-junio), pp. 221-252 
Los sueños de la globalización (re)producen banana republics.

Dossier

Óscar Figueroa como crítico de la globananalización

pesar de que este tipo de creación -al menos cuando presenta rasgos comercializables- se ve también amenazada de absorción canibalizada por parte de la industria cultural.

En este artículo interesa, precisamente, realizar una aproximación a la crítica y la resistencia a la globananalización que se desarrolla en el campo de las artes visuales contemporáneas. Siguiendo a Brian Holmes, citado por Chantal Mouffe (2007, p. 60), quien considera que "el arte puede ofrecer una oportunidad para que la sociedad reflexione colectivamente sobre las figuras imaginarias de las que dependen su propia consistencia, su autocomprensión", analizaré las modalidades de cuestionamiento y oposición al proceso de globananalización que, desde hace aproximadamente una década, lleva a cabo un trabajador del arte contemporáneo: Oscar Figueroa Chávez. Para una mejor comprensión de su aporte crítico, se realiza, primero, una aproximación a los orígenes de la modernidad periférica y la conformación de las llamadas banana republics.

\section{Arqueología de la modernidad periférica}

A mediados del siglo XIX, Domingo Faustino Sarmiento (2009), intelectual y político argentino, considerado hasta hoy uno de los fundadores de la pedagogía latinoamericana, planteó la versión liberal del dilema regional en una fórmula notable por su economía de lenguaje, pero también por sus implicaciones políticas, sociales y culturales: "civilización o barbarie". Esas palabras sintetizaron el programa de construcción nacional que las élites liberales de América Latina venían imaginando desde la independencia, el cual se convirtió en una autoimpuesta y, con frecuencia, despótica misión civilizatoria. Así, los nuevos titulares del poder criollo pensaban arrancar a sus nóveles países de la edad media colonial y fundar naciones modernas, inspiradas en las promesas de la razón iluminista.

La vertiente racista y autoritaria de ese programa se vio reforzada, hacia fines del siglo XIX, con los aportes científicos del programa positivista, que también pergeñó su propio lema: "orden y progreso", estampado hasta hoy en más de un emblema nacional latinoamericano. Pese a las contradicciones que pudieran existir entre el programa liberal y el programa positivista, en nuestra región ambos se fusionaron y combinaron sus lemas, "civilización o barbarie" y "orden y progreso", con lo cual cifraron el programa de la modernidad periférica latinoamericana ${ }^{5}$.

5 Sobre las tensiones doctrinales entre liberalismo y positivismo, ver el importante ensayo introductorio de Oscar Terán al volumen editado por él mismo, América Latina: positivismo y nación (1983).

ESCENA. Revista de las artes, 2021, Vol. 80, Núm. 2 (enero-junio), pp. 221-252 
Ese programa liberal-positivista tenía su base material en el proceso de reinserción de las economías en el mercado mundial que se desarrollaba gracias al empuje de la revolución industrial, el colonialismo europeo y el naciente imperialismo norteamericano. La región se constituía como proveedora de materias primas para satisfacer las demandas del Centro, al expandir su frontera agrícola y actividad minera, intensificar sus métodos de explotación de los recursos naturales y la fuerza de trabajo, así como establecer venas abiertas y centrífugas de comunicación, mediante la construcción de ferrocarriles y puertos para transportar los productos de la tierra y el trabajo hasta los barcos que los llevarían al Norte.

El lado oscuro de ese programa se hace evidente en las medidas orientadas a generar un expansivo e intenso proceso de acumulación primitiva de capital por la vía del despojo o -Harvey (2005) dixit- por desposesión: expropiar la poca tierra que las comunidades indígenas -denominadas manos ociosas por los adalides de la civilización- habían logrado conservar durante el periodo colonial, proletarizar violentamente a los indios "perezosos" y a los negros cimarrones en nuevas haciendas y explotaciones mineras, sin olvidar su movilización forzada para la construcción de vías de comunicación y transporte, así como para servir de carne de cañón en las guerras fronterizas mediante las cuales los países de la región se disputaban territorios apetecibles.

En cuanto a su sustrato cultural, el programa incluía elementos que en principio podrían considerarse positivos, como la secularización, la adopción de la razón y el pensamiento científico, la alfabetización, la promoción de las artes y la reconstrucción de los cascos centrales urbanos, donde se ubicaron parques, paseos y teatros modernos. Los liberales, hijos rebeldes de los conservadores, se alejaban de los templos y el catecismo, para leer novelas y asistir a los teatros, donde escuchaban embelesados el canto de los nuevos dioses y, desde luego, lucían la última moda europea. Sin embargo, ese programa también estuvo plagado de componentes culturales negativos, pues su desprecio por lo nativo y lo popular resultó en la formación de un colonialismo interno legitimado en el eurocentrismo y el despotismo ilustrado, el cual justificaba la explotación y la exclusión de los "bárbaros" y sus formas

El autor contrasta el lema liberal "libertad, igualdad y fraternidad" y el slogan "orden y progreso", mostrando que -si bien ambas doctrinas postulan la centralidad de la razón- el organicismo y darwinismo propios del positivismo son la negación misma de los postulados de la revolución francesa. Sin embargo, esa incompatibilidad doctrinaria no habría impedido que las élites latinoamericanas las combinaran para llevar adelante un programa civilizatorio sobre bases despóticas pretendidamente ilustradas.

ESCENA. Revista de las artes, 2021, Vol. 80, Núm. 2 (enero-junio), pp. 221-252 
Los sueños de la globalización (re)producen banana republics.

Dossier

Óscar Figueroa como crítico de la globananalización

de expresión y vida. La nueva élite pertenecía al linaje de los conquistadores, que a la vez que renovaban su sangre "azul" mediante alianzas matrimoniales con inmigrantes del norte que venían a hacer la América, se arrogaban el monopolio de la razón y la cultura, repitiendo el gesto de sus ancestros, quienes se habían atribuido el monopolio de la religión verdadera.

Por su parte, los sectores populares también engrosaban sus filas con inmigrantes pobres de diversos orígenes, principalmente afroantillanos, asiáticos y sureuropeos. Algunos de aquellos que estaban sometidos a un programa intenso de explotación en las haciendas o en las minas, comenzaron a exigir derechos, inspirados en parte por las noticias y las doctrinas anarquistas y socialistas que llegaban de Europa, despertando la ilusión de una futura revolución. Para controlarlos, los nuevos estados establecieron una policía y un sistema penal "científicamente" fortalecidos, de manera que los códigos penales y las penitenciarías benthamianas fueron la contracara dialéctica de las novelas fundacionales y los teatros de ópera.

Así, se estableció un nuevo sistema social, marcado por una dialéctica entre civilización y barbarie, los cuales -contra lo que pensaba Sarmiento- resultaron no ser excluyentes, sino más bien dialécticamente complementarios. En las sociedades latinoamericanas de fines del siglo XIX, los símbolos del progreso y la cultura (en general, copiados deficientemente de Europa por las élites criollas) eran también, como diría el filósofo judío alemán Walter Benjamin (1939), síntomas de la barbarie de origen colonial, aunque refuncionalizados por la modernidad del capitalismo periférico.

\section{Genealogía de las banana republics}

Las naciones centroamericanas no fueron ajenas a estas veleidades que, apropiándonos de una ficción cinematográfica de Werner Herzog (1982), podríamos llamar el "Síndrome de Fitzcarraldo", la versión latinoamericana de El corazón de las tinieblas, novela de Joseph Conrad (2014) reciclada hace no mucho por Vargas Llosa en su novela El sueño del celta (2010). Serán precisamente los discursos y las imágenes que configuren este proceso de civilización bárbara los que vendrán a proveer el repertorio de los símbolos patrios de las balbuceantes comunidades políticas imaginadas centroamericanas. Una vez establecidos esos símbolos de identidad nacional acordes con el programa liberal-positivista, los mismos se convertirán en un campo de batalla, en el que se contrapondrán narraciones, estrategias discursivas, afiliaciones textuales (Bhabha, 2002), que se disputarán el sentido de la nación. Parafraseando a Jorge Luis Borges (1976), podemos decir entonces que la historia de las

ESCENA. Revista de las artes, 2021, Vol. 80, Núm. 2 (enero-junio), pp. 221-252 
naciones centroamericanas no es más que la historia de la disputa, las apropiaciones y las resistencias, de unas cuantas metáforas surgidas al fragor de los procesos civilizatorios liberales-positivistas y las resistencias a los mismos.

Cabe aquí recordar que el arte moderno latinoamericano ha jugado un papel fundamental en ese proceso de construcción de las comunidades nacionales, ya que las academias fueron creadas para formar, según los cánones europeos en uso, a los artistas o especialistas de la forma (plástica, musical, literaria y dramática). Estos se apropiaron del repertorio cultural europeo con el fin de elaborar las imágenes, los símbolos y las narrativas de los estados y las naciones en formación, creando edificios, esculturas y pinturas alegóricas, en las que es común ver a los miembros de la élite retratados con túnicas y accesorios neoclásicos ${ }^{6}$. Ahora bien, desde esos momentos fundacionales hasta la actualidad, la relación del arte con el proceso de construcción de la nación ha pasado por distintos periodos históricos, grosso modo?:

a. Un primer momento constructivo caracterizado por la elaboración de las imágenes fundacionales de la nación, realizado durante el periodo liberal-oligárquico de fines del siglo XIX y principios del XX. El modelo de nación y sus representaciones durante este periodo se construyeron a imagen y semejanza del modelo republicano francés, elaborado a su vez sobre una apropiación neoclásica del pasado grecoromano.

b. Una segunda fase reconstructiva que cuestiona la representatividad de esas imágenes fundacionales y busca ampliar el imaginario de la nación, modificando "el reparto de lo sensible" (Ráncière, 2009), por medio de la incorporación en las representaciones de lo nacional a los "excluidos de la cuenta" (Ráncière, 1996), sobre todo a

6 Para proponer y legitimar su programa político a los ojos del gran Otro europeo, las élites criollas de orientación modernizante se pensaron como herederas de la tradición grecolatina y se identificaron con las figuras del pasado clásico reconstruidas según los cánones del neoclasicismo. Esta construcción se hizo en oposición no solo a la barbarie colonial y al atavismo indígena, sino también ante la amenaza americana. En consecuencia, este lado del mundo pasó a denominarse Latinoamérica en oposición a la América anglosajona, que aparecía como la portadora de una nueva barbarie, tal como quedó plasmado en el movimiento cultural más influyente entre fines del siglo XIX e inicios del siglo XX: el arielismo. Una interesante comparación sobre tres reflexiones contemporáneas mexicanas sobre El Ariel (1900), de José Enrique Rodó, en Castro (2018).

7 Retomo y reelaboro aquí fragmentos de mi artículo "Las imágenes de la nación en tres tiempos" (Villena, 2016).

ESCENA. Revista de las artes, 2021, Vol. 80, Núm. 2 (enero-junio), pp. 221-252 
Los sueños de la globalización (re)producen banana republics.

Dossier

Óscar Figueroa como crítico de la globananalización

los sectores populares, indígenas y afros y, más recientemente, a las mujeres y a las poblaciones sexualmente diversas. Este periodo arranca de manera evidente con la revolución mexicana (1910) y la reivindicación del componente indígena y popular de la nacionalidad, recurrente a lo largo del siglo XX en varios países de la región.

c. Un tercer periodo deconstructivo que inició en Latinoamérica aproximadamente al despuntar la década de 1990, en el cual el arte -primero denominado posmoderno y luego contemporáneo- no se propone ya responder a la pregunta de quiénes somos, propia de los periodos anteriores, marcados por lo que Gerardo Mosquera (2010) ha denominado "la neurosis de la identidad", sino más bien demoler las imágenes, identidades y subjetividades previamente construidas y actuadas, para -parafraseando a Foucalt (1994)- "dejar de ser lo que somos".

Este último momento que, de una u otra forma, postula el anacronismo de la forma Estado-nación, inicia signado por una serie de eventos internacionales, como el derrumbe del socialismo real, el avance del neoliberalismo globalizador y privatizador, el desarrollo de las nuevas tecnologías de la información y la comunicación, la crisis de la modernidad y el surgimiento de la posmodernidad. Esta tercera tendencia en el tratamiento artístico de la identidad nacional, que se corresponde con un nuevo espíritu de la época, postulado por las tendencias filosóficas posmodernas y deconstructivas, se caracteriza ya no por una estética de lo bello, sino más bien de lo sublime. Esto significa que el arte abdica de la tarea -moderna, por excelencia- de construir representaciones, debido a que lo social -o mejor, lo Real, tal como lo conceptualiza el psicoanálisis lacaniano- no es, por principio -plenamente representable o simbolizable (Lyotard, 2004).

Este abordaje acierta tanto en su cuestionamiento a los límites, exclusiones, oscuridades y horrores de los proyectos nacionales anclados en visiones esencialistas, como en

8 El rescate de lo indígena por el arte oficial ha estado asociado con momentos de ruptura revolucionaria. Comienza con la revolución mexicana (1910), donde encuentra una de sus vías de expresión más importantes en el muralismo de los grandes maestros (Rivera, Alfaro Siqueiros y Orozco) y prosigue en otros países, entre los cuales destaca Bolivia, donde se produce fundamentalmente en dos momentos: el periodo de la revolución nacional (1952-1964) y el proceso de construcción del Estado plurinacional (2006-2019). Otro caso interesante es Perú, durante la revolución llevada adelante por Velasco Alvarado (1968-1975); sobre ese proceso, Aguirre y Drinot (2018); sobre de Bolivia, ver Torrez y Arce (2014).

ESCENA. Revista de las artes, 2021, Vol. 80, Núm. 2 (enero-junio), pp. 221-252 
su reivindicación de la diversidad de pertenencias e identidades. Sin embargo, parece ignorar que las opciones posnacionales también pueden resultar funcionales a las exigencias del capitalismo contemporáneo, menos preocupado por imaginar la nación -o más ampliamente, la sociedad- de manera más abierta e inclusiva, que interesado en derrumbar los obstáculos al libre flujo del capital, entre los cuales se cuentan, desde luego, las identidades nacionales y las soberanías estatales.

A estos procesos generales, corresponde, en el campo del arte, una transición desde lo moderno hacia lo contemporáneo, proceso que comienza a experimentarse en la región Centroamericana a inicios de la década de 1990. No obstante, así como en el istmo la modernidad asumió siempre una forma propia (más que incompleta o inconclusa), ocurre algo similar con lo contemporáneo, puesto que, si bien se difunden y se adoptan -no sin resistencias- pautas artísticas globales, también se añaden un conjunto de especificidades regionales y locales.

Como sea, con el fin de las guerras civiles y el agotamiento de la alternativa revolucionaria, lo que da lugar a la transición a la democracia ${ }^{9}$ y al libre mercado globalizado, ocurren también transformaciones en el campo artístico, en las maneras y escalas en que se produce, circula y ocurre la recepción, valoración y legitimación del arte. Lo que nos interesa destacar es que esa recepción y canibalización de lo contemporáneo en Centroamérica ha implicado no solo una incipiente inserción en los mercados artísticos internacionales como proveedores de diversidad, sino también la emergencia de nuevas formas de hacer crítica y resistencia, de pensar e intervenir desde el campo artístico en los problemas sociales, políticos y culturales que enfrenta la región ${ }^{10}$.

9 En Costa Rica, donde no existió la alternativa revolucionaria, pero sí se configuró un mínimo estado social de derecho y se alcanzó un relativo estado de bienestar, la transición es menos hacia la democracia que hacia un mercado plenamente globalizado, lo que implica aplicar políticas neoliberales destinadas desmontar totalmente el Estado social y productivo y, cada vez más, los derechos ciudadanos conquistados. Desde luego, esto tiene también como consecuencia la erosión de las narrativas de la identidad nacional construidas a fines del siglo XIX y revisadas a lo largo del siglo XX.

${ }^{10} \mathrm{He}$ tratado las transformaciones del campo artístico en Centroamérica en textos previos, como El perro está más vivo que nunca. Arte, infamia y contracultura en la aldea global (2015), "The Ut(r)opian Globalization of Contemporary Central American Art. Tracing the Pale of Histoy or (Furtively) Stolen from the Global Pie" en Critical Cartography of Art and Visuality in the Global Age (Guasch \& Jiménez, 2014) y "La internacionalización del arte contemporáneo costarricense" (2019).

ESCENA. Revista de las artes, 2021, Vol. 80, Núm. 2 (enero-junio), pp. 221-252 
Los sueños de la globalización (re)producen banana republics.

Dossier

Óscar Figueroa como crítico de la globananalización

\section{Oscar Figueroa: hacia una crítica de la globananalización}

El trabajo de Óscar Figueroa (nace 1986, vive y trabaja en Costa Rica) ha problematizado esta transición hacia la globalidad neoliberal en Centro América, con énfasis en Costa Rica. Este artista, que cuenta una importante trayectoria en el campo artístico regional'11, sorprende por su capacidad conceptual y su destreza plástica para hibridar, material y semánticamente, los símbolos de la identidad nacional que se han acumulado a lo largo de la historia costarricense, marcada por sus relaciones (como periferia) con diversos centros. Su propuesta crítica sobre la identidad nacional costarricense se ha centrado particularmente en dos momentos fundamentales del devenir de la nación, los cuales pone en relación dialéctica, buscando hacer evidentes las rupturas y continuidades entre los mismos: el periodo republicano del idilio campesino o edad de oro de la sociedad costarricense, propio del liberalismo decimonónico y el periodo de la globalización, característico del neoliberalismo del segundo milenio.

Este artista, formado profesionalmente en artes plásticas, pero también como sociólogo, ha realizado un sostenido proceso de investigación en archivos, con base en el cual produce imágenes y acciones en las que contrasta, sobrepone y somete el pasado a crítica, hibridando dialécticamente los símbolos del momento constitutivo de la nación costarricense con los símbolos del momento actual, en el que la misma existencia de la nación se encuentra en duda (momento deconstructivo). Así, practica el método propuesto por Walter Benjamin (1939) para hacer estallar la historia o, al menos, para narrar la historia a contrapelo: la construcción de imágenes dialécticas -o de imágenes heterogéneas, como prefiere denominarlas Jacques Ráncière (2002)-, le sirve para mostrar -de manera más irónica que trágica, más carnavalesca que dramática- los cambios, pero también las constantes, económicos y culturales que marcan ambas épocas, caracterizadas por la (re)inserción del país en la economía mundial y, como consecuencia, con la (re)imaginación de la nación.

\footnotetext{
${ }^{11}$ Premiación en la Bienal de Artes Visuales de Costa Rica (2007), participación en la Bienal de Artes Visuales del Istmo Centroamericano (Honduras 2008) y en otras exposiciones de arte latinoamericano en escenarios main stream (por ejemplo, Tate-London, 2014 y Bienal de Mercosur, 2015). En el año 2015, tuvo una exposición restrospectiva en el Museo de Arte y Diseño Contemporáneo (MADC) de Costa Rica, con el título On the other side of the railroads, comisariada por María José Chavarría. Para mayor información, ver la página personal del artista (http://oscarfigueroachaves.blogspot.com/2012/07/curriculum.html), así como el catálogo de la mencionada exposición (https://issuu.com/madc/docs/cat_oscar2).
}

ESCENA. Revista de las artes, 2021, Vol. 80, Núm. 2 (enero-junio), pp. 221-252 


\section{Una arqueología dialéctica del dolor: el lado oscuro del pasado}

Figueroa realiza dos operaciones críticas propias del arte contemporáneo: la primera es una sutil intervención sobre el imaginario clásico del nacionalismo bucólico costarricense, al ponerlo en tensión con su propio lado oscuro. Así, contrasta dialécticamente el discurso y los símbolos del idilio campesino con las crudas realidades de la república bananera; lo que, en el discurso oficial, parece una feliz arcadia resulta ser, en la vivencia de los oprimidos, un lugar de pesadilla. En esta dimensión, el trabajo de Figueroa puede ubicarse dentro del segundo momento de las formas de vinculación entre arte y nación, pues está orientado -retomando las categorías de Ráncière (1996)- a evidenciar los desacuerdos, a ampliar los márgenes de lo sensible y, en definitiva, a hacer oír la voz silenciada de los vencidos ${ }^{12}$.

${ }^{12}$ Las referencias críticas a la identidad nacional costarricense relacionadas con la invisibilización oficial del tema "bananero" tiene antecedentes importantes. Un ejemplo temprano es "Banana Thesis" (1973) y "Banano emplumado" (1973), ambas de Victoria Cabezas, sobre las cuales Miguel López comenta: "el simbolismo del banano fue empleado por la artista como una respuesta a los prejuicios y estereotipos con que ella era percibida durante su etapa de estudiante [en Estados Unidos] por su origen centroamericano. Sus obras parodiaban la virilidad masculina y comentaban las relaciones de poder y de violencia asociadas a la producción de bananos y otros productos agrícolas de Centroamérica y el Caribe, los cuales derivaron en ocupaciones militares estadounidense en la región" (citado en Monge, 2019, p. 122). Otra propuesta interesante es "Índice de resbalosidad" (1986), de Otto Apuy, instalación que consiste en un tobogán donde se chorrean varios potes de pintura con los colores de la bandera nacional, los cuales se escurren y se mezclan formando una pasta gelatinosa de color sangre; los tres racimos de banano que cuelgan en la estructura que soporta el tobogán sugieren una relación entre la producción de ese fruto y la metamorfosis de la bandera en mancha de sangre; la instalación fue colocada al lado del Monumento Nacional, cuestionando la visión gloriosa que juega Costa Rica en la alegoría que representa la construcción de las naciones centroamericanas. Por contraparte, el óleo "Trópico" (1960-1974), de Jorge Gallardo presenta cierta visión idílica del universo bananero. Las piezas de Cabezas, Apuy y Gallardo fueron incluidas en la exposición "Las artes visuales en los años 70", curada por María José Monge (Museo del Banco Central, 2019-2020), disponible en línea. En Guatemala, Moisés Barrios ha trabajo de manera sistemática el tema de los "banana countries" (ver su libro Bananópolis, 2014); en año 2017, el MADC presentó una retrospectiva (1996-2016) de la obra de Barrios, con el título "Potasio. Las consecuencias de la abundancia", la cual incluía una sala sobre el papel de la UFCo: "En Sala 1 del Museo habrá una instalación que llenará el espacio con piezas que aluden a las "junglas bananeras", creadas por empresas como la United Fruit Company (UFCO) que no solo tumbó cientos de hectáreas de selvas tropicales, sino que también derribó vidas, economías y gobiernos. Dicha instalación representa la naturaleza cruel de la UFCO: es la escenificación de una tragedia. Racimos de bananos, sillas y machetes pendularán sobre nuestras cabezas como fuerzas incontrolables, amenazantes y violentas" (Revista Íkaro, 2017).

ESCENA. Revista de las artes, 2021, Vol. 80, Núm. 2 (enero-junio), pp. 221-252 
Los sueños de la globalización (re)producen banana republics.

Dossier

Óscar Figueroa como crítico de la globananalización

La segunda operación consiste en hibridar esas imágenes con aquellas que marcan el presente, desde una perspectiva que, de manera curiosa, recuerda a las tesis marxistas más duras. Las imágenes de la nación sobre las que trabaja Figueroa no son únicamente -tampoco principalmente- las que remiten a las superestructuras culturales de la nación, como podrían ser muchos de los símbolos nacionales o las creaciones culturales canonizadas como patrimonio nacional, sino aquellas que se construyen directamente sobre la representación figurativa de su base o estructura económica.

Entre esas representaciones canónicas de lo nacional, denominadas alegorías en la historia del arte local, destaca la alegoría del café, título que pareciera buscar ocultar la doble faz -cafetalera y bananera- de la constitución de la Costa Rica moderna. Sin embargo, esa imagen, que fue popularizada al ser incorporada en el billete de 5 colones, publicitado como uno de los billetes más bonitos del mundo, muestra tanto el café como el banano. Esa doble faz se evidencia también en los emplazamientos: el fresco está ubicado en el lugar más emblemático de la capital (el Teatro Nacional, lugar de la cultura), pero la escena representada ocurre en Puerto Limón (el lugar de la "barbarie").

Precisamente, como crítica a esa idealización de la patria cafetalera mediante la negación de su lado bananero, Figueroa presenta The most beautiful bill (ver imagen 1), obra en la que recorta esos billetes devenidos souvenir turístico, abyectando de los mismos la representación de un trabajador afroantillano que carga un racimo de banano. Con esa intervención, el artista hace evidente que lo nacional excluye elementos (las personas negras y los bananos) que, a pesar de estar presentes en la alegoría como imágenes, son negados en el discurso del idilio cafetalero.

Por su parte, en el año 2014, se organizó la exposición Una crónica de intervenciones, curada por Inti Guerrero (Teor/éTica) y Shoair Mavilan (Tate Modern), que revisita las interenciones políticas, militares y extranjeras en Centroamérica, en la cual indudablemente el tema de las repúblicas bananeras ocupa un lugar central (ver www.teorética.org/portfolio/una-cronica-intervenciones/).

ESCENA. Revista de las artes, 2021, Vol. 80, Núm. 2 (enero-junio), pp. 221-252 
Imagen 1. The Most Beautiful Bill

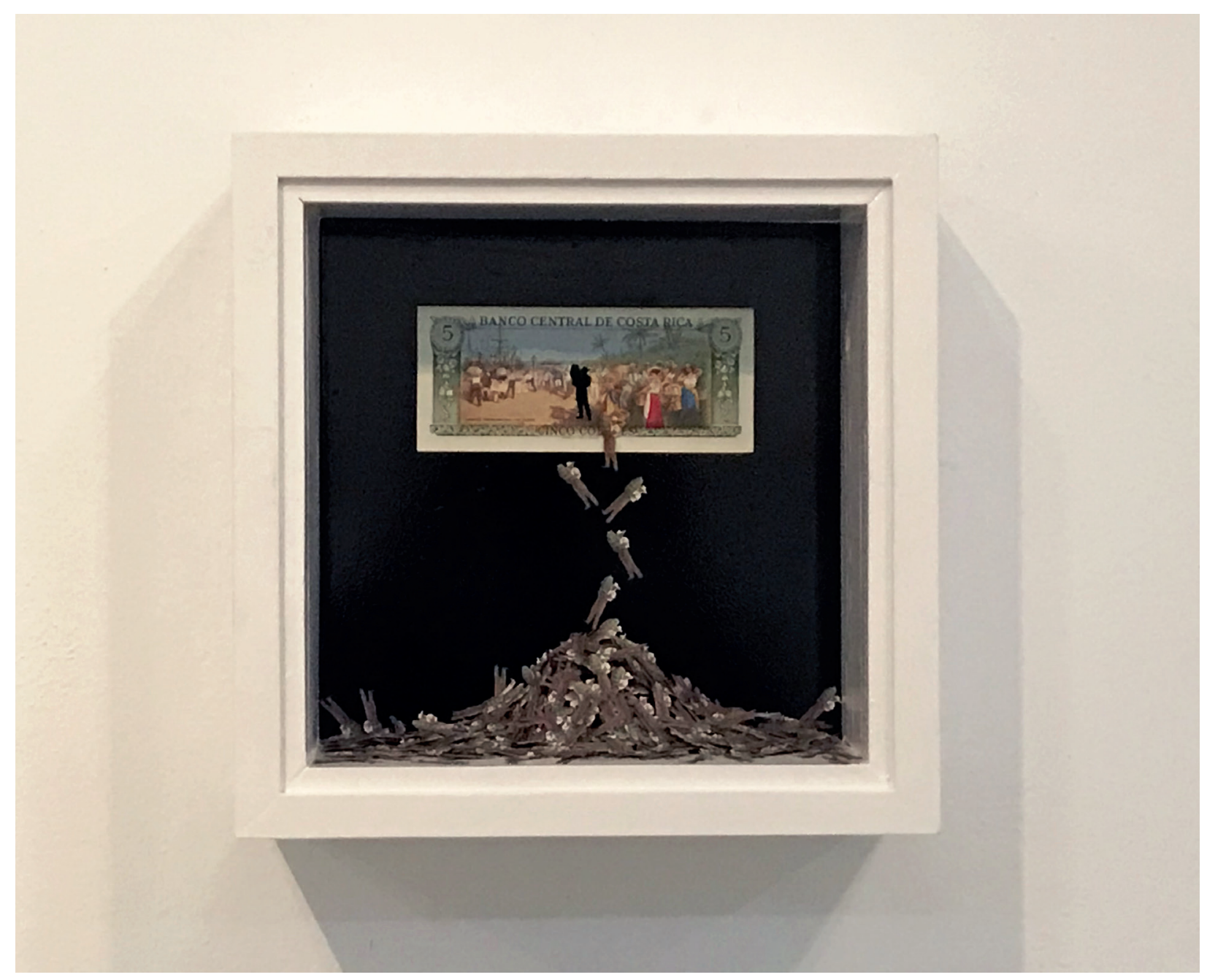

Fuente: Óscar Figueroa.

La obra, compuesta de imágenes y acciones, muestra la articulación entre el café y el banano, los productos fundamentales de la economía costarricense, los cuales están vinculados entre sí por el ferrocarril, que constituye el eslabón perdido que articula esas dos economías de exportación y, por tanto, al idilio campesino con la pesadilla del enclave. Precisamente, una parte importante de la producción de Figueroa está orientada a mostrar 
Los sueños de la globalización (re)producen banana republics.

Dossier

Óscar Figueroa como crítico de la globananalización

el lado bárbaro del ferrocarril, medio de transporte moderno que en el imaginario liberal positivista es por excelencia el símbolo del progreso y la civilización ${ }^{13}$.

En este sentido, recordemos las especificidades históricas de la construcción del ferrocarril al Caribe, mar durante mucho tiempo invisibilizado bajo la denominación de el Atlántico, lo que llevó en algún momento a la curadora Virginia Pérez Ratton (2013) a hablar del "Caribe invisible". La construcción del ferrocarril abrió las puertas a la inversión extranjera directa de capital norteamericano y, de manera fundamental, a la importación de seres humanos, reducidos a su condición de mano de obra extranjera, principalmente afroantillana y china. Sobre los riesgos -de los cuales la historia oficial habla poco o nada- que experimentaban los inmigrantes de origen chino que venían a trabajar en la construcción del ferrocarril, Figueroa realiza 15 nudos (ver imagen 2). Esta obra consiste en un video filmado desde el interior de una caja de madera lanzada a las aguas del mar, con lo cual se reproduce la experiencia aterradora de navegación -a 15 nudos de velocidad- que sufrían los trabajadores que concluían su prolongado viaje en barco desde "el Oriente" hacia la costa centroamericana.

La migración de personas de origen afroantillano y asiático para desempeñarse como trabajadores manuales en el ferrocarril y luego como proletariado agrícola en las plantaciones bananeras, introdujo un factor racial considerado -por sus "fisonomías primitivas" al decir de los críticos de la inmigración laboral- un elemento perturbador en el proceso de formación de la nación costarricense. Esto se relaciona con el hecho de que la identidad nacional fuera definida bajo la consigna de la blanquitud como rasgo racial que se consideraba equivalente de civilización y la glorificación como sujeto nacional -evidente en la letra del Himno Nacional- del sencillo, humilde y esforzado campesino de rasgos "caucásicos" habitante del Valle Central14.

${ }^{13}$ En 1911, la Imprenta del Comercio publicó Los ferrocarriles en Costa Rica. Reseña histórica, de Manuel Sáenz Cordero. Sobre los primeros y frustrados intentos de construcción del ferrocarril, ver el artículo de Jefrey Casey Gaspar, "El ferrocarril al Atlántico en Costa Rica, 1871-1874". Un abordaje antropológico es presentado por Carmen Murillo, en su libro Identidades de Hierro y Humo. La construcción del Ferrocarril al Atlántico 1870-1890. Ver también el libro Keith y Costa Rica de Watt Stewart y el artículo de Rodrigo Quesada, "Ferrocarriles y crecimiento económico: el caso de la Costa Rica Railway Company, 1871-1905".

${ }^{14}$ Existen varios estudios críticos sobre el proceso de construcción de la identidad nacional en Costa Rica. Para el tema que estudiamos, es imprescindible el libro El

ESCENA. Revista de las artes, 2021, Vol. 80, Núm. 2 (enero-junio), pp. 221-252 
Imagen 2. 15 nudos

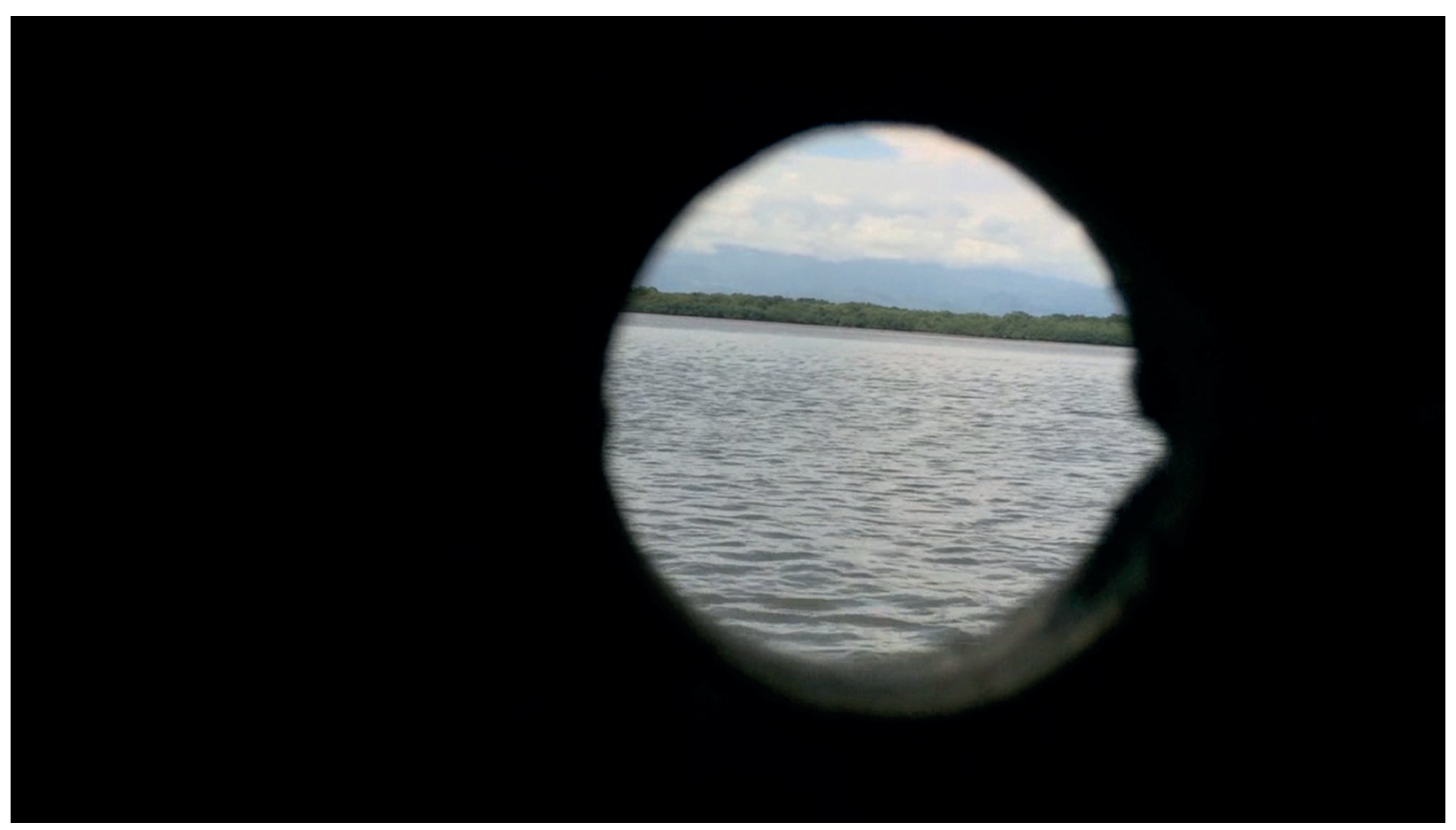

Fuente: Óscar Figueroa.

Figueroa, en sus propuestas, nos recuerda que la modernidad cafetera estuvo marcada por el racismo y la discriminación hacia la población inmigrante afroantillana y china, que fue explotada económicamente, expoliada corporalmente y culturalmente negada durante la construcción del ferrocarril y luego en las plantaciones bananeras, sin que el Estado costarricense hiciera gran cosa por protegerla. Precisamente, para hacer evidente el discurso racista de tinte moderno (positivista-darwinista) con el que se legitimaba el sometimiento racial de los trabajadores negros, el artista colecta viejos durmientes ferroviarios en los que inscribe, mediante talla, fragmentos de textos corporativos con contenido racista, en su obra Inferior race by virtue of [its] subyugation.

imposible país de los filósofos, de Alexander Jiménez (2002). Realicé una reseña de este libro, la cual puede descargarse desde el siguiente vínculo: https://www.academia.edu/32339642/ Nacionalismo_e_imaginación_filosófica_en_Costa_Rica 
Los sueños de la globalización (re)producen banana republics.

Óscar Figueroa como crítico de la globananalización

Ahora bien, ese tipo de discursos no solo eran utilizados por la compañía, sino también por el Estado y no pocos intelectuales costarricenses. Por ello, no es extraño que, por mucho tiempo, el Estado costarricense negara a estas poblaciones el derecho a la ciudadanía y el reconocimiento de su especificidad cultural. Sobre este último tema, Figueroa realiza Fine (Penalti) (ver imagen 3), en la cual presenta una moneda de un colón, que por entonces era el monto de una elevada multa ("Fine") que tenían que pagar las personas afroantillanas cuando eran descubiertas hablando inglés, su lengua materna. Para mostrar metafóricamente la violencia simbólica de esta negación lingüística y cultural, Figueroa hace que la moneda sea aplastada por el paso de una locomotora, es decir, por el progreso.

Imagen 3. Fine (Penalty)

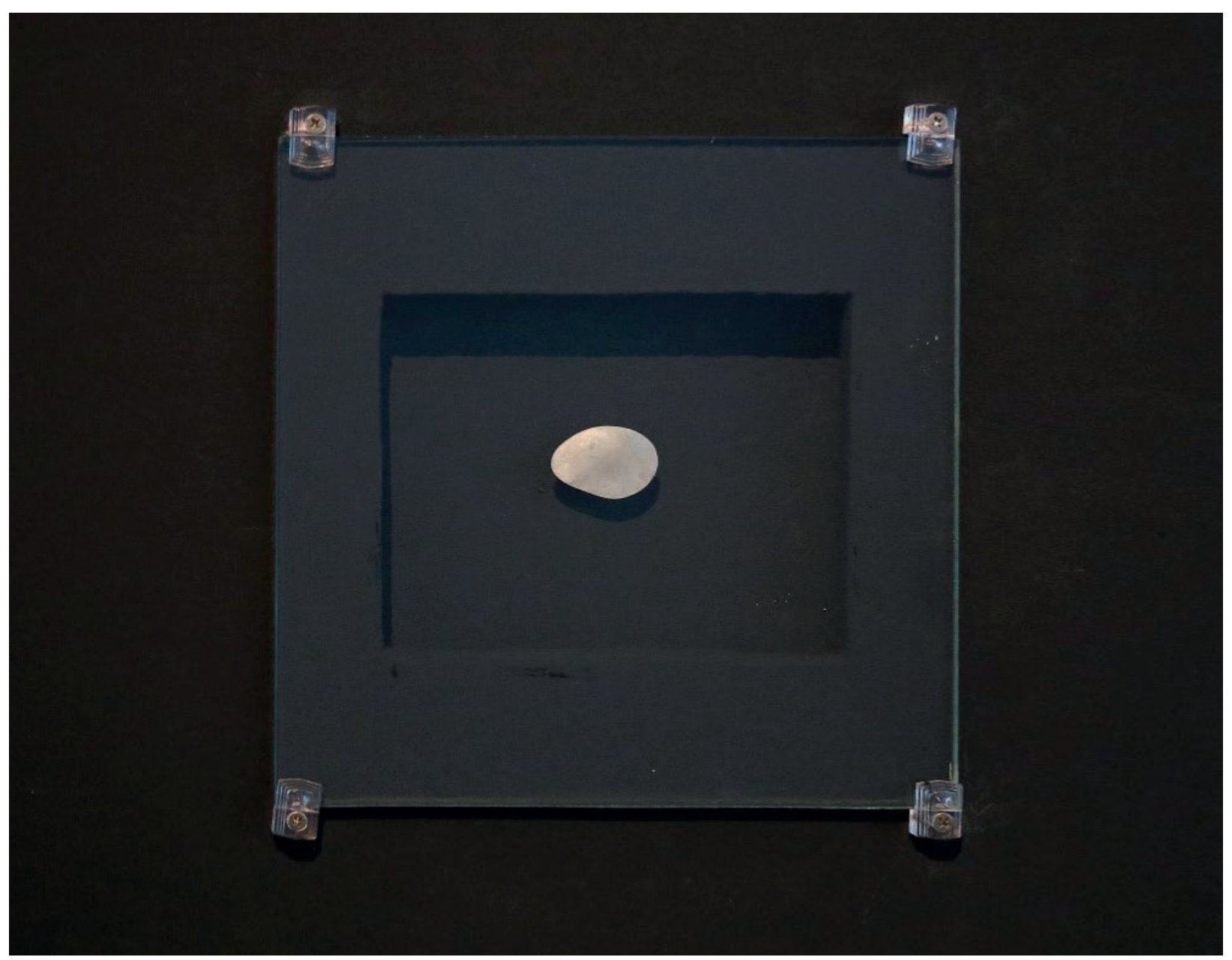

Fuente: Óscar Figueroa

ESCENA. Revista de las artes, 2021, Vol. 80, Núm. 2 (enero-junio), pp. 221-252 
En todas estas propuestas artísticas, Figueroa realiza una suerte de arqueología del dolor provocado por la entrada de Costa Rica en la modernidad. Para ello, recupera, a manera de remembranzas, las huellas del sufrimiento provocado por la barbarie que acompañó la implantación del progreso y la civilización entre las poblaciones de trabajadores extranjeros importados por la compañía ferroviaria. La materialidad de ese dolor está plasmada en los vestigios que quedan adheridos en las ruinas del ferrocarril y que este artista contemporáneo utiliza para evocar ese sufrimiento.

Esa operación, que recuerda el llamado a recuperar la historia de los vencidos que hace Walter Benjamin en sus Tesis sobre filosofía de la historia (1939), se plasma también en obras como Themselves on the beach at low-water (ver imagen 4) y en los dibujos técnicos -otro índice de la racionalidad instrumental moderna- de estructuras ferroviarias que son realizados adhiriendo al papel de dibujo delicados trazos espectrales de los cabellos de las personas trabajadoras chinas que -debido a las inhumanas condiciones de trabajo a las que eran sometidos- solían suicidarse ahorcándose con su propia trenza (ver imagen 5). Esa obra, que puede considerarse una imagen dialéctica realizada con gran destreza técnica, es profunda en su significado social, ya que muestra cómo la monumentalidad del ferrocarril reposa en la fragilidad de la corporalidad y la precariedad in extremis de la vida de los trabajadores inmigrantes.

Imagen 4. Themselves on the beach at low water I

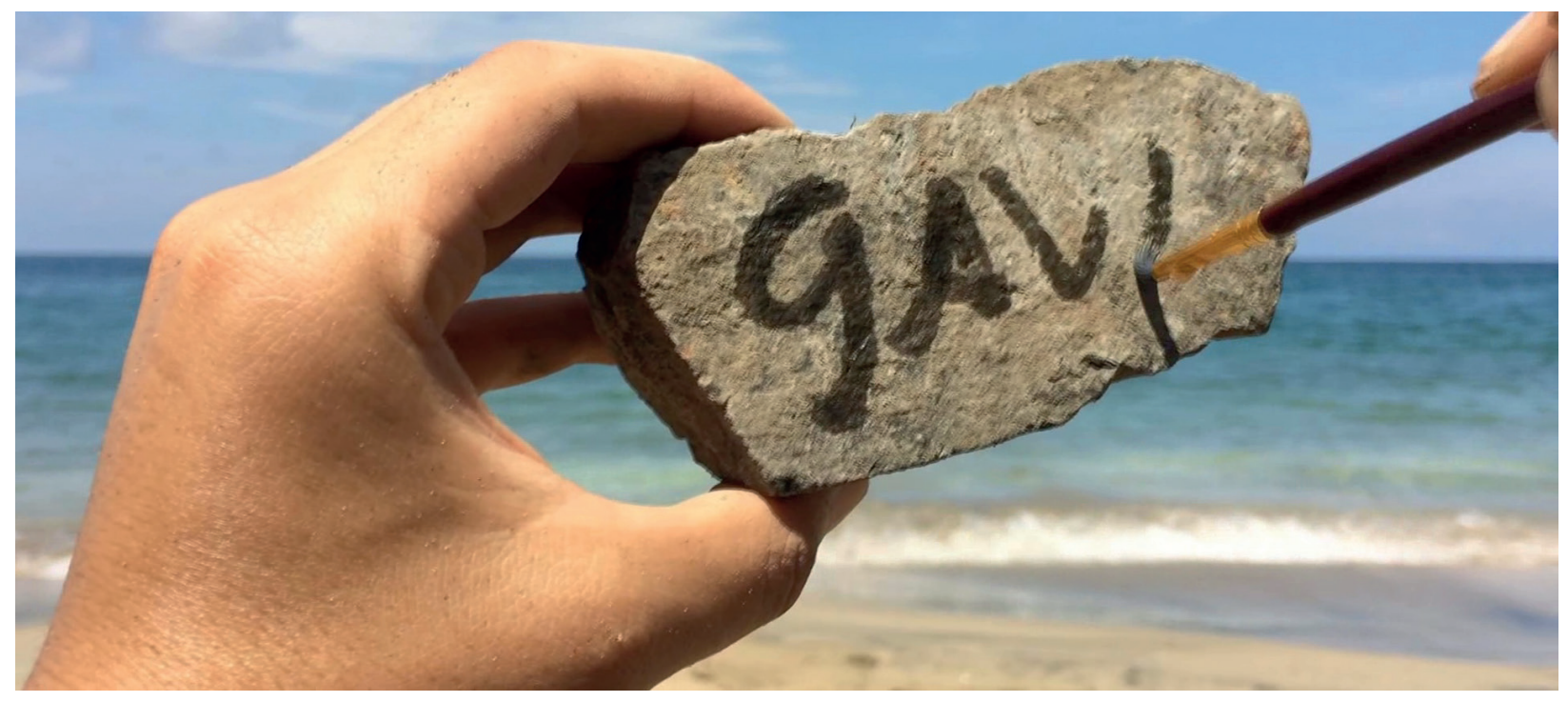

Fuente: Óscar Figueroa

ESCENA. Revista de las artes, 2021, Vol. 80, Núm. 2 (enero-junio), pp. 221-252 
Los sueños de la globalización (re)producen banana republics.

Dossier

Óscar Figueroa como crítico de la globananalización

Imagen 5. Dibujos elaborados con cabello natural de personas chinas de estructuras férreas de Panamá y Costa Rica
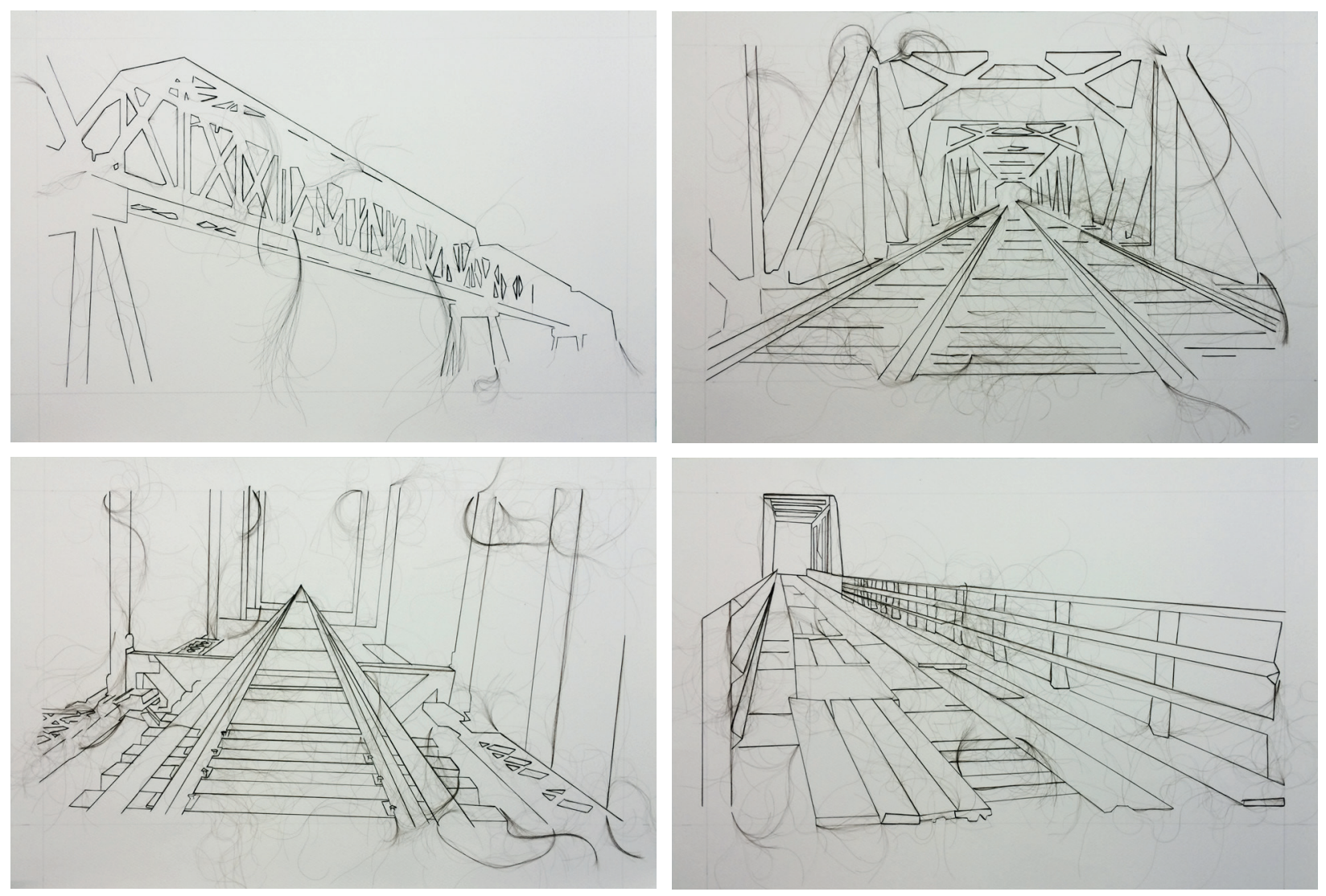

Fuente: Óscar Figueroa

Profundizando en esa temática, Figueroa elaboró réplicas en escala 1:1 de osamentas fracturadas de los trabajadores que participaron en la construcción del ferrocarril. Estas piezas se tallaron sobre residuos de las maderas que fueron utilizadas por la compañía como durmientes sobre los cuales se tendieron las líneas metálicas sobre las que rodaba los convoyes ferroviarios (Fémur, ver imagen 6). Esta obra se inspira en la investigación realizada en archivos por el artista, donde encuentra que el accidente laboral más frecuente que sufrían los trabajadores durante la construcción del ferrocarril era, precisamente, la fractura de fémur por aplastamiento originado en la caída de la pesada carga que debían transportar y que a menudo excedía su capacidad. 
Imagen 6. Fémur

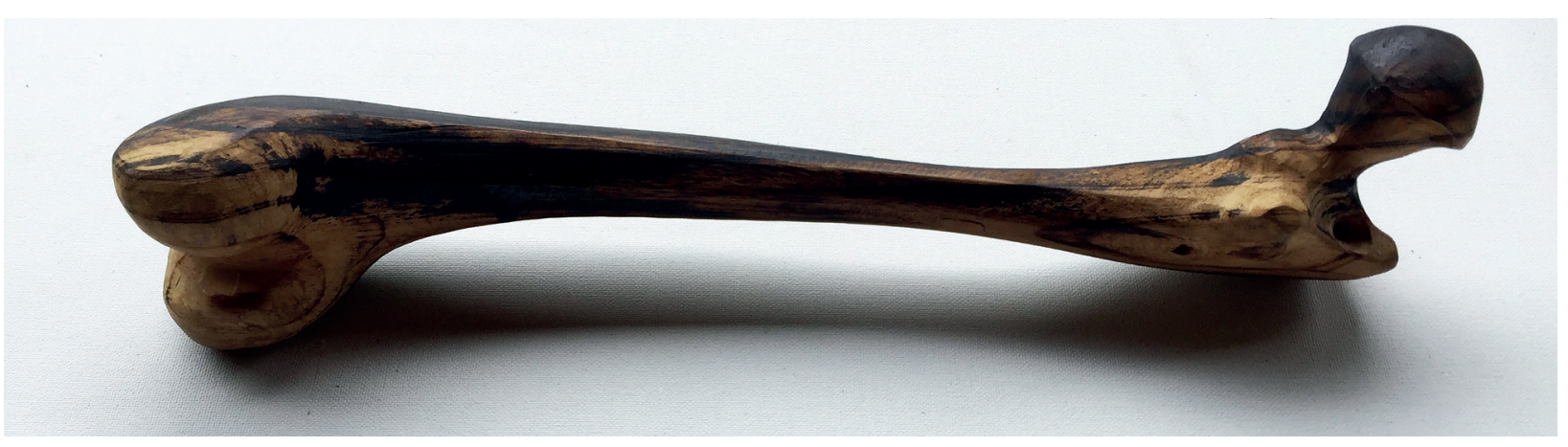

Fuente: Óscar Figueroa.

Finalmente, en su serie Deméritos, realiza varias propuestas utilizando réplicas de las láminas de plástico impregnadas de pesticidas con las que la UFCo cubría los frutos del banano y que causaron esterilidad entre los peones agrícolas. Por ejemplo, expone en el Museo esas hojas plásticas como cuadros artísticos, es decir, como emblemas del progreso; para contrastar dialécticamente esa impresión de alta cultura, Figueroa somete a los visitantes de su exposición a una aterradora experiencia sensorial de inmersión en un espacio saturado de esos materiales tóxicos, con lo que pone en evidencia el lado bárbaro de las condiciones laborales y ambientales del cultivo del banano, las cuales no están muy lejos de las que, dicho sea de paso, caracterizan actualmente al proceso de expansión del cultivo de piña en Costa Rica.

Como una crítica general a esos procesos, el artista realiza también una intervención en el edificio que fue la sede de la UFCo en Puerto Limón (ver imagen 7). La pieza, que tiene una escala monumental, es parte de la serie Deméritos y consiste en cubrir la totalidad del perímetro del edificio de dos plantas con láminas de plástico de color celeste, similares a las utilizadas por la compañía para proteger el fruto del banano del ataque de las plagas. Tal como lo señala en su interpretación de esta obra, la crítica de arte Sofía Villena (2017), Figueroa interviene el edificio formando un cordón sanitario que aísla a la ciudad de Limón (y al país oficial) de la compañía, pero también -en un giro dialéctico esperanzador- hace desaparecer visualmente el edificio, que se confunde con el celeste del cielo ${ }^{15}$.

${ }^{15}$ En su artículo "Marginalized Memories, Architectural Interventions and Reparative Actions in the tenth edition of the Central American Biennale 'Todas las vidas'” (2017)), la autora analiza dos 
Los sueños de la globalización (re)producen banana republics.

Dossier

Óscar Figueroa como crítico de la globananalización

Imagen 7. Intervención antiguas instalaciones de UFco de Li
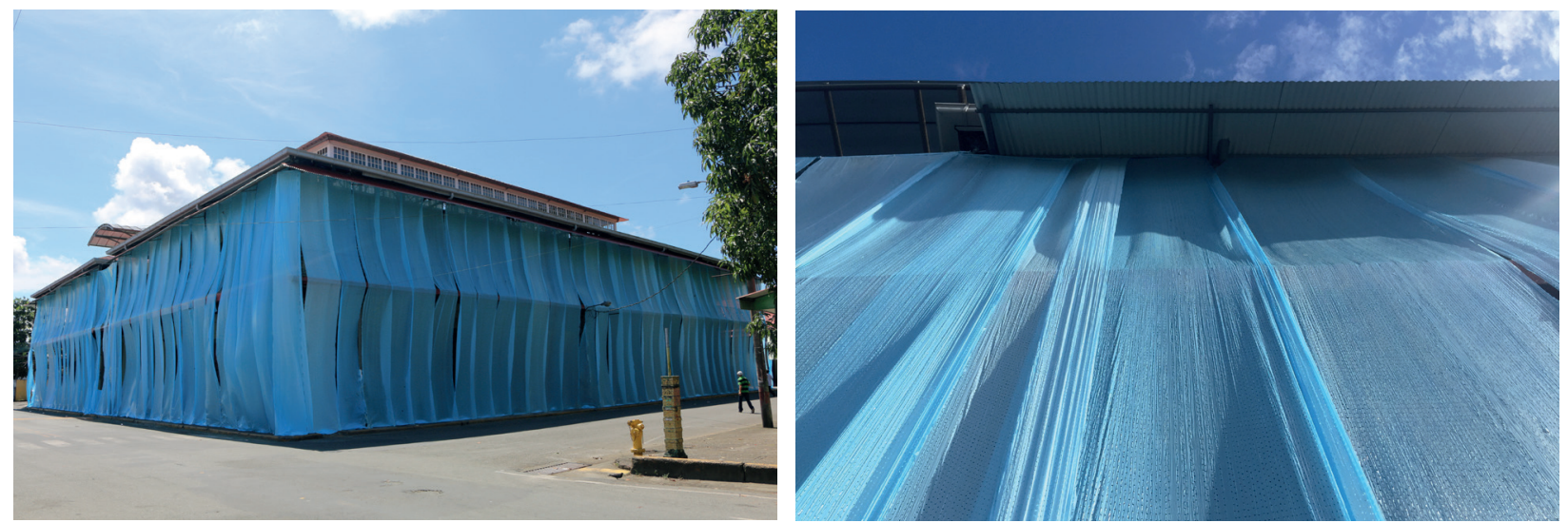

Fuente: Óscar Figueroa

Finalmente, el artista retoma y amplía esta serie con otra pieza, en la cual cubre parte del trazado de la línea ferroviaria hacia el Caribe con ese plástico profiláctico, marcando así la frontera de facto que existía entre el valle central de Costa Rica y el enclave bananero (ver imagen 8). Con ese acto performático, Figueroa enfatiza en el virtual apartheid que existía en el país, puesto que esa línea imaginaria marcaba el umbral más allá del cual no se les permitía el desplazamiento a los trabajadores afrocostarricenses.

intervenciones públicas sobre edificios emblemáticos de la modernidad costarricenses, realizadas una por el artista nicaragüense Marcos Agudelo (el quiosco del Parque Central de San José) y otra por el artista costarricense Óscar Figueroa (el edificio de la UFCo en Limón) . 
Imagen 8. Deméritos

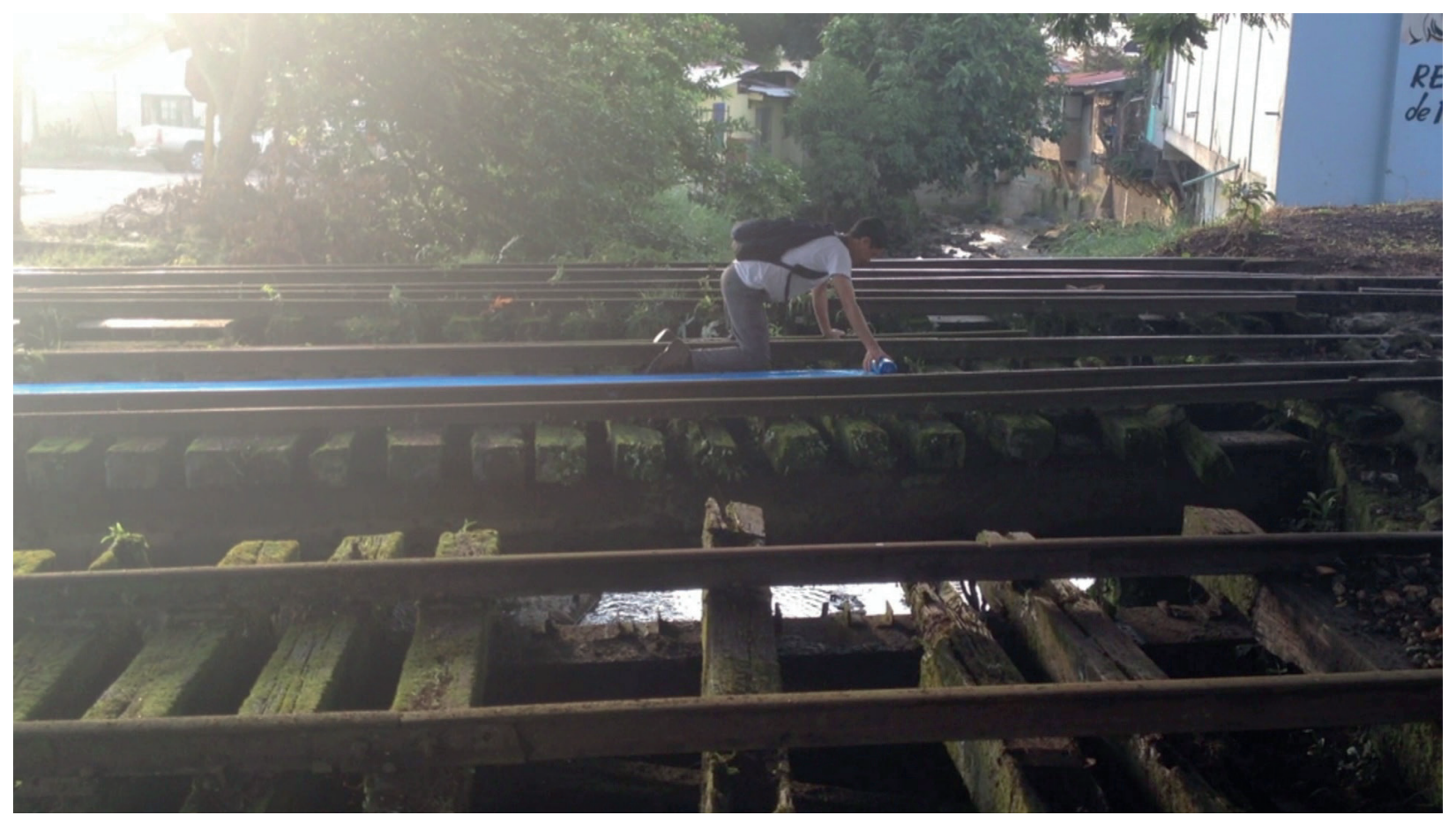

Fuente: Óscar Figueroa.

\section{lluminar el lado oscuro del presente con el pasado negado}

Como artista contemporáneo, Figueroa no solo trabaja produciendo imágenes dialécticas que muestran el lado oscuro del pasado, sino que también pone en relación los vestigios del pasado con el momento actual. En su obra, las imágenes de las explotaciones bananeras y cafetaleras entran en diálogo/tensión con el producto que, desde mediados de la década de los noventa del siglo XX, deviene la principal contribución al PIB y a las exportaciones nacionales, con su contraparte negativa en la balanza de pagos: los circuitos electrónicos/computacionales, producidos como maquila de alta tecnología por compañías transnacionales que están ubicadas en zona franca, forma actual de economía de enclave, como en su época lo fueron las plantaciones bananeras.

En ese ejercicio, Figueroa tensiona el valor de uso, el valor de cambio y el valor simbólico de los bienes producidos en Costa Rica para ser exportados hacia los mercados centrales. Con ello, pone en cuestión el espejismo de la forma para centrarse en la sustancia, es decir, contrapone la economía política a la estética, mostrando que, si bien 
Los sueños de la globalización (re)producen banana republics.

Dossier

Óscar Figueroa como crítico de la globananalización

es evidente que entre el valor de uso del café/banano y los chips de computadora hay un abismo, es también claro que -para una nación periférica- ambos productos son solo valores de cambio, mercancías sujetas a los vaivenes del mercado mundial, que se extraen/ producen para consumo externo. A partir de esa premisa, el artista manipula con notable habilidad simbólica y plástica estos objetos-fetiche (piezas de computadoras, granos de café y racimos de banano), poniéndolos en una nueva constelación de significado. En los discursos nacionalistas globalifilicos del presente, los chips de computadoras se presentan como el nuevo grano de oro, como un renovado equivalente del café, símbolo positivo de la identidad nacional que glorificó la imagen del labriego humilde y sencillo y ocultó sistemáticamente la del peón agrícola en el enclave bananero.

En contraste con ese discurso, Figueroa nos hace ver que, detrás de esa asociación positiva manifiesta, hay una verdad latente menos gratificante: la equivalencia simbólica entre los chips de las computadoras y el banano, ese producto cuya marca estigmática en la historia nacional está reprimida, abyectada, pero que actúa como un fantasma que retorna de manera recurrente y desestabiliza las representaciones gratificantes de la república cafetalera: la imagen de una república bananera. Al poner en tensión el valor de uso y el valor de cambio entre los productos que, a lo largo de la historia, han representado una constante en la vinculación con la economía capitalista mundial, el artista genera un cortocircuito simbólico que pone de manifiesto el carácter subdesarrollado, dependiente y periférico, de la nueva economía.

De ese modo, muestra que más allá del cambio en el valor de uso del producto estrella que, según los mandatos de la época, se produce localmente para consumo en el mercado mundial, este cambio cosmético que sirve de soporte al discurso de la "(pos) modernidad" oculta una verdad que nos negamos a aceptar: seguimos siendo una nación que, aunque produzca -maquile- chips de última generación, mantiene su carácter subalterno en el sistema económico mundial, ya que las decisiones últimas sobre qué, cómo (bajo qué condiciones) y para quién producir no responden a nuestras propias necesidades, sino a los imperativos funcionales de las corporaciones transnacionales y, en definitiva, del sistema capitalista global. Esta equivalencia simbólica anclada en la estructura económica es puesta en evidencia en los trabajos de Figueroa, en los cuales las piezas de computadora, pepenadas entre la basura tecnológica que satura el planeta, transmutan en los "productos estrella" que las preceden: en Sistema Musacea (ver imagen 9), los mouses de computadora se tropicalizan y apilan como racimos de banana protegidos con capas curadas con

ESCENA. Revista de las artes, 2021, Vol. 80, Núm. 2 (enero-junio), pp. 221-252 
Imagen 9. Sistema Musacea

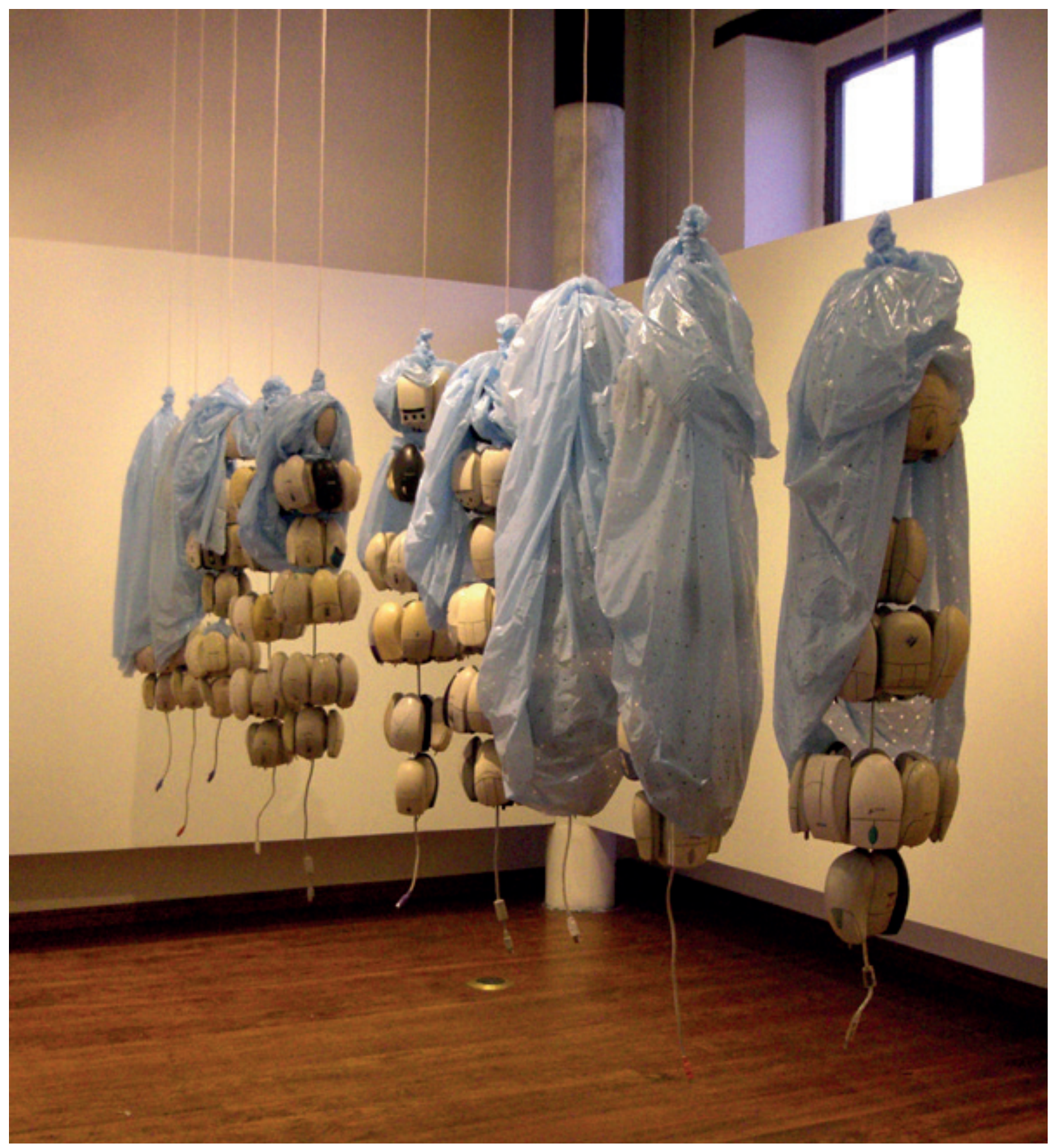

Fuente: Óscar Figueroa.

ESCENA. Revista de las artes, 2021, Vol. 80, Núm. 2 (enero-junio), pp. 221-252 
Los sueños de la globalización (re)producen banana republics.

nocivos pesticidas, como el nemagón, que produjo en las fincas bananeras esterilidad entre los peones, sin que las empresas asuman toda su responsabilidad hasta ahora.

Imagen 10. Proceso de secado

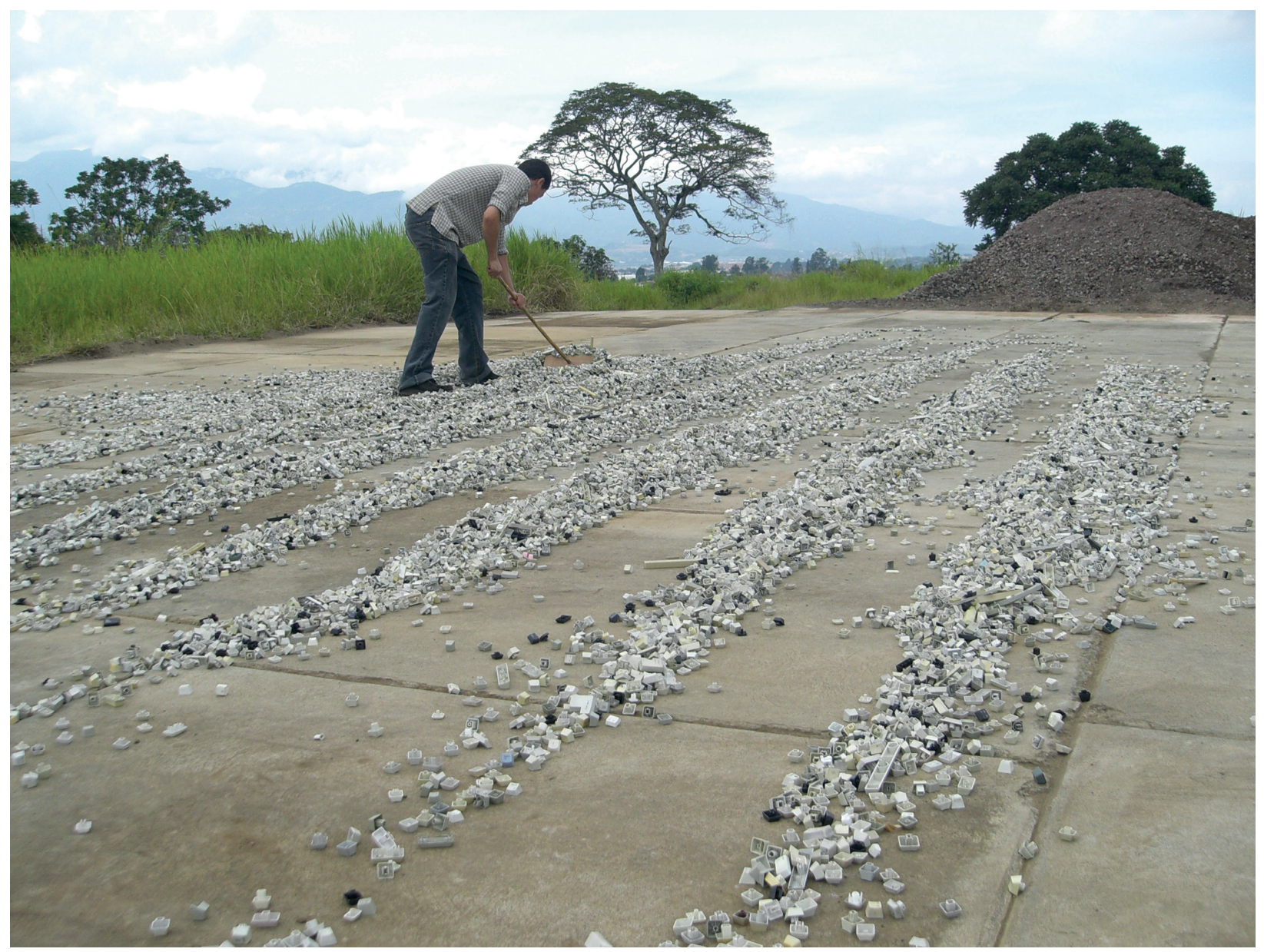

Fuente: Óscar Figueroa.

Del mismo modo, las teclas de computadora se someten a un Proceso de secado (ver imagen 10) y empaque que recuerda a los beneficios de café. Los circuitos de computadora se estampan sobre las hojas de banano y también sobre las imágenes alegóricas que evocan un pasado bucólico; la imagen de un feliz estibador portuario de racimos de banano se sobreimprime -cual logotipo espectral de la nación- en los cajeros automáticos. Los cables de 
computadora se hibridan con las chiras (flores) del banano en una serie infinita, aparentando una siniestra chayotera (enredadera) cyborg, un híbrido tecno-orgánico de mil cabezas que, más que evocar una placidez bucólica del idilio campesino, amenaza con devorar todo lo que está en derredor, como hiciera el pulpo transnacional de la bananera.

Estas hibridaciones entre la economía del pasado y la economía del presente, entre lo orgánico y lo tecnológico, permiten lecturas distintas, incluso contrapuestas, al menos en apariencia. Por un lado, pareciera que el pasado es como un fantasma que recorre Centroamérica y se niega a morir, pues se repite mecánicamente, en un gesto inercial, reflejo, hasta neurótico: la economía ha cambiado, pero persiste su huella cultural, su marca canalla y estigma, que no es otro que el de banana republic. Desde este punto de vista, la pseudomodernidad tecnológica no hace mella en la economía de postre que históricamente ha caracterizado a la economía ístmica; es decir, no cuestiona el arcaísmo cafetalero o la inercia bananera, que persisten como la marca de la identidad nacional de banana/café republic.

Por otro lado, en dirección contraria, el presente tecnológico -pero no por eso desarrollado- coloniza al pasado, lo resignifica, lo resemantiza, lo canibaliza; se apropia de su huella cultural, le imprime su sello, se presenta como su continuidad, más que como una ruptura. Pretende ser el resultado natural del devenir histórico, la actualización del telos que marcó el inicio de la historia gloriosa de la nación, destinada a ser global, a la vez que periférica, desde siempre...o, al menos, desde que las elites criollas, asociadas al capital transnacional, hicieron suya la carga del hombre blanco y decidieron arrancar de la barbarie a sus jóvenes naciones, a los cuales veían por lo general como un apéndice o extensión de sus fincas.

Gracias a las hibridaciones que nos presenta Figueroa, se nos abre una nueva manera de ver/conocer el proceso de imaginación de la nación, de reflexionar sobre el devenir de la identidad nacional costarricense en el marco de la globalización. Las imágenes dialécticas que nos ofrece nos llevan inevitablemente a sospechar que el gran incógnito que desvelaba a aquellos que Alexander Jiménez (2002) denomina filósofos étnico-metafísicos de la primera mitad del siglo XX no es el campesino enmontañado productor de café, sino el proletario agrícola que dejaba su vida en las plantaciones bananeras de la Mamita Yunai, magistralmente retratado por Carlos Luis Fallas en su novela así titulada, publicada en 1941.

Siguiendo a Figueroa, la cifra de la identidad nacional habría que buscarla entonces en la articulación entre los procesos de imaginación de la nación y las exigencias del sistema capitalista mundial, puesto que es este el que, según la época y sus necesidades, 
Los sueños de la globalización (re)producen banana republics.

Dossier

Óscar Figueroa como crítico de la globananalización

refuncionaliza materialmente y recicla simbólicamente a las sociedades periféricas, produciendo una constante reimaginación de la nación. En esa tarea de mostrar la continuidad del colonialismo -externo e interno- poniendo en contraste los rasgos estructurales que subyacen a las distintas etapas de la (trans/de)formación de la nación costarricense, el artista ha iluminado también la oscura problemática racial que atraviesa esa historia ${ }^{16}$.

\section{Apague y vámonos}

¿Pueden las prácticas artísticas desempeñar aún un papel crítico en una sociedad en la que la diferencia entre el arte y la publicidad ha quedado desdibujada y los artistas y los trabajadores culturales han pasado a ser un elemento imprescindible de la producción capitalista?

(Chantal Mouffe, 2007, p. 59).

La respuesta a las interrogantes que Chantal Mouffe (2007) plantea en el epígrafe que abre esta sección final es, sin lugar a dudas: sí, el arte puede aún jugar un papel crítico y emancipatorio. Por lo menos, eso es lo que se puede concluir a partir del análisis e interpretación de la obra de Óscar Figueroa, la cual es una importante contribución a la comprensión del presente centroamericano, sobre el que interviene iluminando dialécticamente el lado oscuro -bananero, precisamente- que se esconde tanto en el idilio campesino pergeñado a fines del siglo XIX, como tras la globalización neoliberal que arranca en el ocaso del siglo XX.

${ }^{16}$ En años recientes, junto con las maquilas de alta tecnología que se instalan en las zonas francas de Costa Rica, donde gozan de exenciones impositivas y se benefician de la infraestructura estatal sin contribuir a su construcción y mantenimiento, se han instalado múltiples trabajos modernos y flexibles, como los de operadores de call centers, choferes de Uber, arrendatarios de Airbnb y repartidores que "colaboran" con transnacionales varias. Como en otras partes, estas nuevas modalidades de trabajo -menos celebradas por los adalides de la globalización que las maquilas tecnológicas- han contribuido a precarizar el trabajo y a difuminar las barreras entre lo público y lo privado, como entre lo nacional y lo global (de hecho, un tema central para los gobiernos ha sido cómo regular este tipo de servicios, que fácilmente escamotean las obligaciones fiscales y las leyes laborales que son impuestas a las empresas radicadas en territorio nacional). Hasta donde conocemos, estos temas no han sido aún tratados por artistas contemporáneos costarricenses.

ESCENA. Revista de las artes, 2021, Vol. 80, Núm. 2 (enero-junio), pp. 221-252 
Este artista centroamericano ha asumido la tarea que corresponde a los contemporáneos, la cual -parafraseando la notable formulación de Giorgio Agamben (2014), basada en su lectura de Walter Benjamin y Friedrich Nietzsche- se puede formular en los siguientes términos: confrontar intempestivamente su propio presente, posando su mirada en el lado menos luminoso del mismo, con el fin de extraer de esa oscuridad una pequeña luz que ayude a iluminar el pasado negado, ab-yectado por la historia oficial, pero a la vez poseedor de nuevas posibilidades para el futuro. A lo largo de su extensa y destacada trayectoria artística, Figueroa muestra que, al menos en el caso de Costa Rica, la mutación del ser nacional y el modelo de desarrollo ha transitado desde el nacionalismo étnico metafísico, propio del periodo republicano, hacia el globalismo técno-bucólico, manteniendo sin solución de continuidad una posición periférica y dependiente constante en el sistema capitalista global.

La obra que hemos estudiado a lo largo de este texto es resultado de un minucioso trabajo de investigación social y experimentación artística orientado por una postura crítica, que pasa el cepillo creativo a contrapelo a la historia oficial, para poner en cuestión tanto la llamada época dorada de la formación de la identidad nacional, como el momento presente. De esa forma, esa labor crítica muestra que, tras las cegadoras luces y espejismos del mercado global, se ocultan las facetas siniestras del capitalismo canalla, en el que Centroamérica se inserta en la segunda mitad del siglo XIX y que, en las últimas décadas del siglo XX e inicios del XXI, asume la forma de una globananalización.

Gracias a su solidez conceptual y a su prolija resolución plástica, Figueroa nos impacta e invita a reflexionar sobre cómo ese tránsito, que se verifica paulatinamente y con sus propios matices en el resto de los países de la periferia, incluidos aquellos que han dado el salto de tigre tecnológico, está marcado por una constante: el carácter persistente de la dependencia y el colonialismo -externo e interno- que tiene como resultado un renovado proceso de "desarrollo del subdesarrollo" (Frank, 1967). Es decir, nos hace reflexionar sobre cómo la expansión global del capitalismo canalla sobre los países del istmo centroamericano (re)produce la gloBANANAlización, con sus secuelas de formas renovadas de enclavitud/ esclavitud, poniendo en cuestión los discursos celebratorios que producen narrativas civilizatorias según las cuales esos momentos de inserción en la globalidad asimétrica aparecen precisamente como los de mayor realización del proyecto nacional. 
Los sueños de la globalización (re)producen banana republics.

Dossier

Óscar Figueroa como crítico de la globananalización

\section{Referencias}

Agamben, G. (2014). Desnudez (¿Qué es lo contemporáneo?). Barcelona: Anagrama.

Aguirre, C. \& Drinot, P. (editores). (2018). La revolución peculiar. Repensando el gobierno militar de Velasco. Lima: IEP.

Barrios, M. (2014). Bananópolis. Guatemala: Editorial Rara y Dinamita Libros Arte.

Benjamin, W. (1939). Tesis sobre filosofía de la historia. Recuperado de http://www.anticapitalistas.org/IMG/pdf/Benjamin-TesisDeFilosofiaDeLaHistoria.pdf

Bhabha, H. (2002). El lugar de la cultura. Buenos Aires: Manantial.

Borges, J. L. (1976). La esfera de Pascal. Otras inquisiciones. Madrid: Alianza Editorial.

Cardenal, E. (2019). Hora Cero. Ernesto Cardenal. Poesía completa. Madrid: Trotta.

Castro, B. (2018). José Enrique Rodó en tres ensayistas mexicanos: Carlos Fuentes, Carlos Monsiváis y Enrique Krauze. Latinoamérica. Revista de Estudios Latinoamericanos, 66. Recuperado de https://www.redalyc.org/jatsRepo/640/64058222007/html/index.html

Conrad, J. (2014). El corazón de las tinieblas. México: Sexto Piso.

Fallas, C. L. (2008). Mamita Yunai. San José: Editorial Costa Rica.

Foucault, M. (1994). Hermenéutica del sujeto. Madrid: La Piqueta.

Frank, A. G. (1967). El desarrollo del subdesarrollo. Pensamiento Crítico, 7, 159-172. Recuperado de http://www.filosofia.org/rev/pch/1967/pdf/n07p159.pdf

Harvey, D. (2005). El "nuevo" imperialismo: Acumulación por desposesión. Recuperado de http://biblioteca.clacso.edu.ar/clacso/se/20130702120830/harvey.pdf

Herzog, W. (1982). Fitzcarraldo. Alemania: Werner Herzog Filmproduktion / Wildlife Films Peru.

Hirschman, A. O. (1970), Exit, Voice, Loyalty: Responses to Decline in Firms, Organizations, and States. Cambridge, Mass.: Harvard University Press. 
Jiménez, A. (2002). El imposible país de los filósofos. San José: Arlekin.

Lyotard, F. (2004). La condición posmoderna. Madrid: Cátedra.

Lyra, C. (1931). Bananos y hombres. Recuperado de http://www.lospobresdelatierra.org/ textos/lyrabananosyhombres.html

MADC (coordinación de Rosina Cazali) (2016). El día que nos hicimos contemporáneos. XX aniversario del MADC. San José: MADC

MADC (editor) (2015). On the other side of the railroads - Óscar Figueroa Chaves (Catálogo de exposición). San José: MADC

Monge, M. J. (2019). Artes visuales en los setenta = Visual arts in the seventies. San José: Fundación Museos Banco Central de Costa Rica.

Mosquera, G. (2010). Caminar con el diablo. Textos sobre arte, internacionalismo y cultura. Madrid: Exit Publicaciones.

Mouffe, C. (2007). Prácticas artísticas y democracia agonística. Barcelona: MACBA / UAB, Universitat Autónoma de Barcelona.

Murillo, C. (1995). Identidades de Hierro y Humo. La construcción del Ferrocarril al Atlántico 1870-1890. San José: Editorial Porvenir.

Neruda, P. (1950). La United Fruit Co. Canto General. Recuperado de http://www.cervantesvirtual.com/obra/canto-general--0/

Pérez-Ratton, V. (2013). Del estrecho dudoso a un Caribe invisible. Apuntes sobre arte centroamericano. Valencia: Universitat de València.

Ráncière, J. (1996). El desacuerdo. Política y filosofía. Buenos Aires: Nueva Visión.

Ráncière, J. (2009). El reparto de lo sensible. Santiago: LOM.

Rendueles, C. (2015), Capitalismo canalla. Una historia personal del capitalismo a través de la literatura, Barcelona: Seix Barral.

Robinson, W. I. (2019). La Segunda Implosión de Centroamérica. Tensões Mundiais - Edição Temática: América Central, 15(28). Recuperado de https://revistas.uece.br/index.php/ 
Los sueños de la globalización (re)producen banana republics.

Dossier

Óscar Figueroa como crítico de la globananalización

tensoesmundiais/article/view/1120

Sarmiento, D.F. (2009). Facundo. Villa María: Editorial Universitaria Villa María.

Stewart, W. (1991). Keith y Costa Rica. San José: Editorial Costa Rica.

Terán, O. (editor) (1983). América Latina: positivismo y nación. México: Editorial Katún.

Torrez, Y. \& Arce, C. (2014). Construcción simbólica del Estado Plurinacional. Imaginarios políticos, discursos, rituales y celebraciones. La Paz: PIEB.

Vargas Llosa, M. (2010). El sueño del celta. Madrid: Alfaguara.

Villena Araya, S. (2017). Marginalized Memories, Architectural Interventions and Reparative Actions in the tenth edition of the Central American Biennale 'Todas las vidas'. ESCENA. Revista de las artes, 77(1), 1-16. Recuperado de https://www.redalyc.org/ jatsRepo/5611/561161114009/index.html

Villena, S. (2014a). The Ut(r)opian Globalization of Contemporary Central American Art. Tracing the Pale of Histoy or (Furtively) Stolen from the Global Pie, A. M. Guasch y N. Jiménez (editoras). Critical Cartography of Art and Visuality in the Global Age. Cambridge Scholars Publisher.

Villena, S. (2014b), Construcciones / Invenciones: Las imágenes de la nación en tres tiempos. MADC (curada por María José Chavarría), Catálogo exposición Construcciones/ Invenciones. San José: MADC.

Villena, S. (2015). El perro está más vivo que nunca. Arte, infamia y contracultura en la aldea global. San José: Germinal.

Villena, S. (2018), Memories of the Glo-Ba-na-na-Lization. Geoeconomy and Contemporary Art in Central America Critical Cartography of Art and Visuality in the Global Age. En R. Pinilla y C. Grammatikopoulou (eds.). Critical Cartography of Art and Visuality in the Global Age II. The Territories of the Contemporary. Cambridge University Press.

Villena, S. (2019). La internacionalización del arte contemporáneo costarricense, Centroamericana, 29 (1), 177-206. Recuperado de https://www.academia.edu/41170829/ La_internacionalización_del_arte_contemporáneo_costarricense

ESCENA. Revista de las artes, 2021, Vol. 80, Núm. 2 (enero-junio), pp. 221-252 